\title{
Scientific Text Language and Expression
}

\author{
Prof. Dr. Mahmudov Nizomiddin
}

\author{
Director of Institute of Uzbek language, literature and folklore of the Uzbekistan Academy of Sciences \\ DOI: 10.29322/IJSRP.11.12.2021.p12003 \\ http://dx.doi.org/10.29322/IJSRP.11.12.2021.p12003
}

\begin{abstract}
This article discusses the problems of textual linguistics as one of the most pressing issues in linguistics. It is emphasized that the movement of language in cognitive function and its activity as a product of this action is directly reflected in scientific texts. In addition, scientific texts have a special place in the typology of non-fiction texts. It is also noted that expressiveness in a scientific text differs from expressiveness in an artistic text by certain peculiarities. While expressiveness in a scientific text serves to concretize a concept, it has been proven to serve to create an image in fiction.
\end{abstract}

Index Terms- text, scientific text, language, expression, literary text, style, cumulative, cognitive function.

\section{INTRODUCTION}

$\mathrm{I}_{\mathrm{p}}^{\mathrm{t}}$ is well known that language is a complex and magnificent phenomenon that forms the basis of human society, realizes all its evolution and aspirations, ensures the existence and unity of this society, and therefore has a number of functions. It is the sum of these tasks that determines its great essence. The holistic nature of language cannot be determined on the basis of only one particular of these functions. It should not be forgotten that in addition to the communicative function, "language performs a number of functions, such as knowing the world, collecting, storing knowledge, transmitting it to future generations, reflecting spiritual relationships, realizing beauty categories... Interpreting language only as a means of communication between people regulates traffic by regulating human natural language, this incredibly complex and magnificent phenomenon, at the very least, from directing it to an artificial language (such as Esperanto) that is completely alien to a particular national image or nationalspiritual ground. is nothing more than a conditional "language" created for the purpose of constructing" [3, p. 44].

\section{IDENTIFY, RESEARCH AND COLLECT IDEA}

The cognitive function of language certainly leads in the knowledge of the infinite mysteries of the world, in the development of its endless puzzles, but its other functions also, to one degree or another, are in motion, in cooperation. Or, for the aesthetic function of language to be activated and for the realization of a particular artistic intention, of course, its communicative, cognitive, and other functions are also not at all intertwined.

It is also impossible to completely separate the cognitive function of language from its cumulative (knowledge storage), communicative and other functions, because as a human being decides to explore the world, he is necessarily in need of communication with people and their experiences and distance in space is eliminated by the cumulative and communicative functions of language.

The famous Uzbek philologist A.Rustamov described this glorious virtue of language in such a popular way that we will never forget to remember this clear description: "Every child born must know a lot in order to become a real person. He learns by seeing, hearing, and reading the knowledge he needs. Learning to hear and read takes place through language, and its possibilities are endless. If there were no language, and everyone's life was based on his own experience, man would have lived as the animal did to this day, and would not have achieved today's material and spiritual progress. The first enlightening significance of language is that the knowledge generated by each member of society through language becomes popular and can be developed by the majority. Furthermore, because of language, knowledge is passed from generation to generation orally or in writing, with the result that the new generation continues it without having to start the work of the previous generation anew. This will ensure further development" $[8$, p. 4]. This means that knowledge is passed on from generation to generation through language.

It is safe to say that knowing the world, that is, knowledge and science, does not come to a certain level all at once. In the words of the well-known philosopher, theorist and historian of the last century M.K.Petrov, "science did not appear in an absolute vacuum and can not be the result of assimilation" [5, p. 233]. This scientist, who has studied the history of world science, emphasizes that in any component of any science there are results obtained as a result of past and present researchers, pre-existing knowledge, as well as other relevant results are integrated with modern science through a "quote network" emphasizes that it is a fundamental principle in the development of any science.

The movement of language in cognitive function and its activity as a product of this action is directly reflected in scientific texts.

The text is so unique and complex that it took a long time to comprehend it with its features as a whole. At almost all stages of the history of linguistics, sound, word, and finally speech have been studied. For a long time, only speech was studied as the basic unit of expression of language, and even judgments were made about the end of linguistics where speech ends. But since the second half of the last century, the idea that the largest, highest communicative unit in language is the text has begun to stabilize, making it clear that people communicate with each other not through words but through texts. Indeed, there is no need or necessity to prove that a completely complete thought, content, 
information can be expressed only in the text, not in the sentence. The direction of textual linguistics has emerged in linguistics in different countries of the world. Today, in Uzbek linguistics, more serious research has been conducted in the field of textual linguistics. Problems of textual linguistics have been put on the agenda as the most pressing issues in linguistics.

Structural connection and semantic-logical integrity are among the basic and fundamental qualities of the essence of the text, which integrate the movement and relations of language tools in the whole text area. It is known that the term "text", an alternative to the text in Russian, is derived from the Latin word "textus", the original meaning of which is "woven fabric, weave, join, join" (remember the word "textile"), which means one of the units in the text. - can emphasize that they have merged and merged with each other. The following comments of the German linguist K.Boost on the relationship of units in the text are particularly noteworthy: "The threads drawn from one sentence to another form so many and so strong that it is possible to speak of the intertwining of the words, that they are woven as a single net, because each individual sentence is closely connected with the others" [11, p. 33].

It should also be noted that the correct and complete understanding of the text as a whole "woven fabric", "woven net", the development of the laws of the relationship of contentstructural elements in it, the full study of linguistic and psychological mechanisms associated with its creation and understanding not a very comfortable job. At the same time, to visualize non-verbal content in the text, to grasp the author's aesthetic intentions, to rely on certain knowledge in order to adequately understand the various gestures in the text, in particular, presupposition [6, p. 28-31] will also be required. Otherwise, the opportunity to be fully aware of the purpose of the author of the text is lost.

In the study of texts, it is customary in linguistics to distinguish, first of all, their two opposing types, namely: 1) literary text and 2) non-literary text. Noting the need to distinguish between the two opposing types of texts, M.Yuldashev writes: 87]. Russian linguist N.S.Valgina says that the most important features of non-fiction and non-fiction text are often noted as: 1) the presence / absence of a direct connection between human activity and the text; 2) the presence / absence of an aesthetic function; 3 ) explicit / implicit content (presence / absence of subtext); 4) focus on the same understanding / non-focus on the same understanding; 5) Orientation to reflect a real being / Orientation to reflect a nonreal being (literary texts represent models of probable real beings that are consciously structured, not a model of a real being). At the same time, he argues that the literary text is based on the laws of associative-figurative thinking, the non-fiction text is based on the laws of logical thinking, the fictional text affects the emotional perception of the individual, the fictional text affects the intellectual aspect, and finally these two types of texts differ in function. emphasizes that communicative-informational, and literary text serves communicative-aesthetic functions [10, p. 6970]. The opinions of the two scholars on the texts of the Uzbek and Russian languages, which are completely different from each other, complement each other.

\section{IMPROVEMENT AS PER REVIEWER COMMENTS}

This publication is licensed under Creative Commons Attribution CC BY

http://dx.doi.org/10.29322/IJSRP.11.12.2021.p12003
Of course, scientific texts have a special place in the typology of non-fiction texts. However, it should be noted that from these points of view, the scientific text is not aesthetically pleasing or, say, expressiveness at all, and it is incorrect to conclude that the scientific text is completely free of expressiveness.

Obviously, the degree of expressiveness in a literary text cannot be equated with the expressiveness in a scientific text, but this does not mean that expressiveness is completely alien to the scientific text. Nevertheless, a misconception has been formed that many believe that a scientific text should be without expression, and even some researchers try to avoid expressive expressions and images as much as possible in the statement of their scientific research. It is no secret that a number of qualities of the scientific style, such as accuracy, logic, neutrality, are interpreted as an obstacle to the expression of expressive-emotional, according to which the language of the text written in this style becomes more "dry". The language of the information statement in such texts, the style of expression, often does not excite the reader.

Describing the scientific method of the Russian language, O.A.Krilova states the following firm judgments: "Emotionalexpressive painting is alien to the scientific method of the Russian language. Both the lexicon inherent in the scientific style and the choice of morphological forms, as well as the nature of word order and syntactic constructions, are aimed at ensuring the accuracy, logic, objectivity and abstraction of the statement. The emotional color of speech does not allow these goals to be achieved. Expressive means of language, in particular, emotionallyexpressive colored vocabulary, figurative means are not typical of scientific style " [2, p. 101].

In the monograph of M.Mukarramov, who studied the scientific method of the Uzbek language, we find the following comments: "While some functional styles allow expressiveemotional, some do not. In particular, scientific and official document speeches are free of emotional expressiveness. Because the demand for these types of speech is unique. On the contrary, speech and artistic discourse are expressive-emotional " [4, p. 64].

The following words of the well-known Russian linguist D.E.Rosenthal are noteworthy: When scientists talk about language, they often say that their language is "dry" and devoid of emotional and figurative elements. Such an approach is the result of excessive generalization: often in scientific works, especially in controversial texts, emotional-expressive and figurative means of language are used, which, as an additional method, stand out against the background of pure scientific narration and give additional reliability to scientific prose " [7 , p. 32].

Neither from the point of view of the Russian language, nor from the point of view of the Uzbek language, it is impossible to fully agree with these views. It is not expedient to completely deny any expression in any scientific text.

Clearly, no scientist or researcher will ever be indifferent to how an idea he or she is trying to convey is expressed, that is, how it is understood and, of course, received, as new information he or she finds as a result of painstaking research. The compiler wants the product of his mental creation to be understood correctly, adequately, to be believed in it, to be recognized, so he tries to create as effective a speech as possible. One of the main ways to ensure sensitivity is to create expressiveness.

Of course, expressiveness in a scientific text differs from expressiveness in an artistic text in certain respects. First of all, 
expressiveness in a scientific text serves to concretize a concept, while it serves to create an image in fiction. As the researchers rightly point out, "the expressiveness of literary language is a high degree of imagery, and in a scientific text it is an indicator of reliability" [1, p. 24]. Expressiveness in a scientific text, along with reliability, stimulates not only the rational but also the emotional perceptions of the reader (or listener) of the text, of course.

The following passage from the work of the great Uzbek linguist A. Gulomov allows us to imagine how much the metaphor in the combination of haqiqiy hayotga ega bo 'lish concretizes the scientific concept, the value of expression in the scientific text:

Given that a sentence is made up of words, phrases, and that words are used in a sentence, in the process of expressing an idea, in real life - in speech, it is understood that syntax is also related to lexicon. (G'ulomov A., Asqarova M. Hozirgi o'zbek adabiy tili. Sintaksis. -Toshkent: O'qituvchi, 1987. -B.10).

Or it can be seen that the sharp irony in this passage from the work of academician A.Khojiev has created a strong expressiveness in the scientific text: First, there is no such thing as an "independent component of a word," meaning that the phrase "independent component of a word" does not mean anything, including any linguistic concept. Therefore, it cannot be said that there is a branch (doctrine) of linguistics that studies the "independent component of the word" (what doctrine can there be about something that does not exist?!) (Hojiev A. O'zbek tili

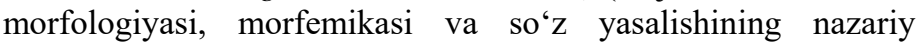
masalalari. -Toshkent: Fan, 2010. -B.35).

In the following passage of text from this source, the expression "not fair" also served to express the content of "incorrect" in a softer, rather than neutral, expression: Furthermore, the above considerations regarding morphemes were specific to other linguistics, including Russian linguistics. The ideas that existed in Uzbek linguistics were mainly copies of ideas in Russian linguistics. Consequently, it would not be fair to attribute the errors and omissions in this regard to any expert, or to calculate the errors and omissions of any linguist (p. 29).

Again in the following passage from the same source it is impossible not to notice that units such as chala-chulpa were involved in the formation of expressiveness: Unfortunately, almost no attention was paid to this issue. This is the reason why our work on the study of Uzbek language systems is in a state of disrepair (p. 20).

There are many types of linguistic tools that create expressiveness in a scientific text. In particular, downloads (amplification, separation-limitation), different levels of quality and forms, emotionally-expressive coloring words, and so on. Parables, metaphors, and other stylistic figures not only give vitality to the statement, but also serve as one of the most acceptable ways of expressing complex, abstract concepts more clearly and vividly [1, p. 24].

\section{CONCLUSION}

Of course, when talking about expressiveness in a scientific text, it is necessary to keep in mind the specifics of the sciences. In science, all fields of knowledge are classified into the exact sciences, the natural sciences, and the social sciences and humanities. Expressiveness and emotionality in the texts of the exact and natural sciences may not be reflected brightly and systematically in accordance with the essence of those sciences, but to a certain extent it cannot be denied that they also have this feature. But it is no exaggeration to say that expressiveness is a necessary element in the texts of the social sciences and humanities. Well-known Kazakh writer Oljas Suleymanov's words reflect the truth: "Physics and mathematics need their own language. Imitating such" serious sciences "kills the humanities, especially linguistics, simply put ... By its very nature, the social sciences otherwise, they must be understandable, otherwise they will not be able to perform their function " [9, p. 11-12].

The more the author tries to put the movement and life of linguistic elements in the field of scientific text, the more vivid and clear the text, the more responsible the editor must be. In particular, an editor who relies on text editing in the social sciences and humanities should keep in mind the need for expressiveness of the text.

\section{REFERENCES}

[1] Dyadyura G., Kolesnik D. Kategoriya ekspressivnosti $\mathrm{v}$ sovremennih nauchnih tekstah // Upravlenie i obrazovanie. Tom VII (2), 2011.

[2] Kojin A.N., Krilova O.A., Odinsov V.V. Funksionalnie tipi russkoy rechi. M.: Visshaya shkola, 1982.

[3] Mahmudov N. Ma'rifat manzillari. - Toshkent: Ma'naviyat, 1999.

[4] Mukarramov M. Hozirgi o'zbek adabiy tilining ilmiy stili. -Toshkent: Fan, 1984.

[5] Petrov M.K. Yazik, znak, kultura. -M.: Nauka, 1991

[6] Presuppozisiya haqida batafsil qar.: Mahmudov N. Presuppozisiya va gap // O'zbek tili va adabiyoti. - 1986. - N6. - B.28 - 31 .

[7] Rozental D.E. Prakticheskaya stilistika russkogo yazika. -M.: Visshaya shkola, 1974

[8] Rustamov A. So'z xususida so'z. -Toshkent: Yosh gvardiya, 1987.

[9] Suleymenov O. Yazik pisma. -Almati - Rim, 1998.

[10] Valgina N.S. Teoriya teksta. - M.: Logos, 2003.

[11] Yo`ldoshev M. Badiiy matn lingvopoetikasi. -Toshkent: Fan, 2008.

\section{AUTHORS}

First Author - Prof. Dr. Mahmudov Nizomiddin, Director of Institute of Uzbek language, literature and folklore of the Uzbekistan Academy of Sciences 